\title{
PENERAPAN BIMBINGAN KELOMPOK MODEL PERMAINAN BELAJAR BERSIKAP UNTUK MENINGKATKAN KEMAMPUAN PENYESUAIAN DIRI SISWA SEKOLAH MENENGAH PERTAMA (SMP)
}

\author{
Triandriyani dan Hermien Laksmiwati \\ Jurusan Psikologi Pendidikan dan Bimbingan Universitas Negeri Surabaya \\ e-mail:hermien_laksmiwati@yahoo.com
}

\begin{abstract}
Abstrak: Tujuan dari penelitian ini adalah untuk menguji keefektifan penerapan bimbingan kelompok model permainan belajar bersikap untuk meningkatkan kemampuan penyesuaian diri di sekolah. Penelitian ini menggunakan rancangan pre-eksperimen berupa "pre-test" dan "post-test one group design”. Subjek dalam penelitian ini adalah 8 siswa kelas VII SMPN 1 Diwek, Jombang dengan skor kemampuan penyesuaian diri di sekolah rendah. Metode pengumpulan data yang digunakan adalah angket. Teknik analisis data yang digunakan adalah statistik non-parametik dengan Uji Jenjang Bertanda Wilcoxon yang menunjukkan adanya perbedaan yang signifikan pada skor kemampuan penyesuaian diri di sekolah antara sebelum dan sesudah perlakuan. Berdasarkan hasil Uji Wilcoxon diketahui bahwa $\mathrm{T}_{\text {hitung }}=0$, dengan $\mathrm{N}=8$ dan taraf signifikan 0,05 maka $_{\text {tabel }}=4$. Berarti $\mathrm{T}_{\text {hitung }}$ lebih kecil dari $\mathrm{T}_{\text {tabel }}(0>4)$, sehingga hipotesis penelitian diterima dan dapat disimpulkan bahwa bimbingan kelompok model permainan belajar bersikap merupakan pendekatan yang efektif untuk membantu siswa meningkatkan kemampuan penyesuaian diri di sekolah.
\end{abstract}

Kata kunci: Bimbingan kelompok, kemampuan penyesuaian diri di sekolah.

Setiap individu memiliki kemampuan yang berbeda untuk berinteraksi dengan lingkungannya. Beberapa individu mampu menyesuiakan diri dengan cepat dan baik dengan lingkungan barunya sehingga tidak akan mengalami hambatan dalam pergaulan. Penyesuaian diri akan menumbuhkan rasa optimis dan positif yang dapat mendorong anak berbuat lebih banyak dan teliti sehingga kemungkinan berhasil akan diperolehnya. Sebaliknya, individu yang kurang bisa menyesuaiakan diri berpeluang untuk mengalami kegagalan dalam proses pendidikan dan pembelajarannya. Individu yang kurang mampu menyesuaikan diri terhadap lingkungannya akan mengalami perasaan tertekan karena merasa dikucilkan dari pergaulan. Hal ini sesuai dengan pandangan Panut Panuju (2005: 37) yang menyatakan bahwa individu yang tidak dapat menyesuaikan diri akan memiliki kekurangan-kekurangan sehingga akan merasa terasing dan terisolir dari lingkungan masyarakat di mana dia hidup.

Permasalahan penyesuaian diri di sekolah mungkin akan timbul ketika remaja mulai memasuki jenjang sekolah yang baru. Mereka mungkin mengalami permasalahan penyesuaian diri dengan guru, teman, maupun mata pelajaran yang baru. Perpindahan dari lingkungan yang lama ke lingkungan masyarakat yang baru seringkali menyebabkan remaja mengalami kesulitan dalam membentuk persahabatan dan hubungan sosial yang baru. Salah satu upaya yang dapat dilakukan untuk memperlancar proses penyesuaian diri remaja, khususnya di sekolah, adalah dengan pelaksanaan progam bimbingan dan penyuluhan yang sebaikbaiknya (Sunarto, 1999: 238-239).

Salah satu layanan yang dapat diterapkan dalam membantu pemecahan permasalahan penyesuaian siswa adalah layanan bimbingan kelompok. Aktivitas kelompok diarahkan untuk memperbaiki dan mengembangkan pemahaman diri dan lingkungan, penyesuaian diri serta pengembangan diri (Juntika, 2006: 23). Bimbingan kelompok merupakan suatu pemberian bantuan (bimbingan) yang diberikan kepada 
peserta didik melalui kegiatan kelompok. Dalam layanan bimbingan kelompok, aktivitas dan dinamika kelompok harus diwujudkan untuk membahas berbagai hal yang berguna bagi pengembang-an dan pemecahan masalah siswa yang menjadi peserta layanan.

Teknik yang dapat diterapkan dalam layanan bimbingan kelompok adalah teknik umum dan permainan kelompok (Tohirin 2007: 173). Permainan dapat dijadikan sebagai salah satu teknik dalam layanan bimbingan kelompok baik sebagai pelengkap teknik-teknik yang lain maupun sebagai suatu teknik tersendiri yang merupakan wahana pemuat materi pembinaan atau materi layanan tertentu.

Menurut Prasetyo (2007: 68), melalui kegiatan kelompok bermain akan diperoleh berbagai pengalaman yang dapat digunakan untuk memperbaiki hubungan antar manusia dan mengenal diri sendiri dengan lebih baik. Senada dengan pendapat Prasetyo di atas, Mulyono (2002: 4) menyatakan bahwa melalui permainan akan tercipta suatu suasana yang menyenangkan. Melakukan beberapa latihan permainan dalam suasana yang rileks akan membuat peserta mendapat pengalaman tersendiri. Dalam permainan tersebut peserta didik dapat melampiaskan dorongan-dorongan emosinya sehingga tercipta perasaan lega dan puas. Suasana menyenangkan dan santai yang tercipta selama permainan berlangsung akan menimbulkan suatu pengalaman tersendiri bagi peserta didik yang kemudian akan direnungkan untuk menyadari perasaan dan reaksi-reaksi mereka. Dinamika kelompok yang tercipta juga akan mendorong peserta didik untuk mampu melakukan interaksi sosial sehingga peserta didik akan mampu menyesuaikan diri secara baik dan wajar dalam lingkungan sosialnya.

Berdasarkan latar belakang masalah di atas maka timbul satu pertanyaan besar, yaitu apakah bimbingan kelompok model permainan belajar bersikap dapat meningkat-kan kemampuan penyesuaian diri siswa di sekolah.

\section{Bimbingan Kelompok Model Permainan Belajar Bersikap}

Menurut Juntika (2006: 23), bimbingan kelompok merupakan bantuan terhadap individu yang dilaksanakan dalam situasi kelompok. Bimbingan kelompok dapat berupa penyampaian informasi ataupun aktivitas kelompok yang membahas masalahmasalah pendidikan, pekerjaan, pribadi, dan sosial. Senada dengan Juntika, Tohirin (2007: 170) menyatakan bahwa layanan bimbingan kelompok merupakan suatu cara memberikan bantuan (bimbingan) kepada individu (siswa) melalui kegiatan kelompok. Dalam layanan bimbingan kelompok, aktivitas dan dinamika kelompok harus diwujudkan untuk membahas berbagai hal yang berguna bagi pengembangan atau pemecahan permasalahan individu yang menjadi peserta layanan.

Adapun keunggulan bimbingan kelompok menurut Prayitno dalam Nursalim (2002: 53) meliputi beberapa aspek, yaitu (a) menyangkut aspek ekonomis/efisiensi, yaitu dengan adanya kelompok akan semakin banyak orang yang dibantu sehingga relatif membutuhkan waktu yang lebih cepat; (b) dengan adanya interaksi yang intensif dan dinamis diharapkan tujuan bimbingan dapat tercapai secara lebih mantap; (c) dinamika yang terjadi dalam kelompok mencerminkan suasana kehidupan nyata yang dapat dijumpai di masyarakat.

Secara umum, layanan bimbingan kelompok bertujuan untuk pengembangan kemampuan bersosialisasi, khususnya kemampuan berkomunikasi siswa. Secara lebih khusus, layanan bimbingan kelompok bertujuan untuk mendorong pengembangan perasaan, pikiran, persepsi, wawasan, dan sikap yang menunjang perwujudan tingkah laku yang lebih efektif, yakni peningkatan kemampuan berkomunikasi baik verbal maupun nonverbal para siswa (Tohirin, 2007: 172). 
Menurut Jumhur dan Surya (dalam Nursalim, 2002: 57), teknik-teknik yang ada dalam bimbingan meliputi home room, karya wisata, diskusi kelompok, kegiatan kelompok, remidial teaching, psikodrama, sosiodrama, bermain, dan kerja kelompok. Permainan juga dapat dijadikan sebagai salah satu teknik dalam layanan bimbingan kelompok baik sebagai selingan maupun sebagai wahana yang memuat materi pembinaan atau materi layanan tertentu. Permainan kelompok yang efektif dan dapat dijadikan sebagai teknik dalam layanan bimbingan kelompok harus memenuhi ciriciri sederhana, menggembirakan, menimbulkan suasana santai dan tidak melelahkan, meningkatkan keakraban, dan diikuti oleh semua anggota kelompok.

Penerapan model permainan ini telah berkembang lebih dulu di Eropa dan Amerika. Salah satu tokoh yang mengembangkan model permainan ini adalah Klaus Vopel yang telah mengumpulkan, mengembangkan, dan menerapkan banyak sekali permainan interaksi di Jerman (Siregar, 1993: xxiii). Mulyono (2002:4) menyatakan bahwa melalui permainan akan diciptakan suatu suasana yang menyenangkan. Melakukan beberapa latihan permainan dalam suasana yang rileks bisa memberikan suatu pengalaman bagi peserta. Melalui pengalaman yang diperoleh, peserta didik diajak untuk menghayati pengalaman tersebut kemudian merenungkannya sehingga mereka bisa menyadari perasaan dan reaksi-reaksi fisik mereka. Selanjutnya mereka diajak untuk mengungkapkan hal-hal yang dialami waktu latihan atau permainan berlangsung. Pengalaman yang diperoleh kemudian diolah secara kelompok bersama pembimbing dengan cara mendiskusikannya dan menarik kesimpulan.

Dari uraian di atas dapat diambil kesimpulam bahwa bimbingan kelompok model permainan belajar bersikap adalah suatu kegiatan bimbingan yang diberikan kepada sekelompok individu atau murid untuk membantu menyelesaikan masalah. Masalah pendidikan atau pengajaran, pekerjaan, situasi sosial, dan sebagainya dapat diatasi dengan permainan belajar bersikap yang berguna untuk merangsang dan membina pengalaman-pengalaman pribadi atau kelompok.

Menurut Siregar (1993: 6), prosedur pelaksanaan permainan secara umum melalui beberapa tahap, yaitu tahap permulaan, tahap bermain, dan tahap evaluasi. Pada tahap permulaan, fasilitator mengusulkan suatu permainan/latihan dan menjelaskan cara bermain serta peraturan permainan. Ia harus memastikan bahwa setiap peserta sudah mengerti permainan yang akan dijalani.

Pada tahap selanjutnya, tahap bermain, fasilitator tidak ikut berperan. Hasil dari permainan/latihan yang sedang dijalankan merupakan tanggung jawab kelompok dan masing-masing anggota kelompok. Merekalah yang menentukan proses bermain sedangkan fasilitator hanya mengamati proses bermain supaya dapat dibahas bersama kelompok setelah permainan berakhir.

Tahap terakhir dan yang sangat penting adalah tahap evaluasi. Tahap ini tidak boleh dilewatkan begitu saja karena setelah permainan selesai dan dievaluasi, arti dan makna dari permainan/latihan yang baru dilakukan akan jelas bagi peserta. Pada tahap ini fasilitator mendorong para peserta untuk memikirkan pengalaman-pengalaman mereka yang baru dan memberanikan mereka untuk mengungkapkan perasaannya. Akhirnya, fasilitator dapat menyimpulkan dan menunjukkan hasil ataupun dasar yang penting dari latihan yang telah dilakukan.

\section{Penyesuaian Diri di Sekolah}

Menurut Sunarto (1999: 222), penyesuaian diri adalah usaha manusia untuk mencapai keharmonisan pada diri sendiri dan pada lingkungannya. Sedangkan menurut Sofyan Willis (2005: 55), penyesuaian diri adalah kemampuan seseorang untuk hidup 
dan bergaul secara wajar terhadap lingkungannya sehingga ia merasa puas terhadap dirinya dan terhadap lingkungannya. Dari dua pendapat di atas dapat disimpulkan bahwa penyesuaian diri adalah usaha atau kemampuan seseorang untuk hidup dan bergaul secara wajar terhadap lingkungannya sehingga ia memperoleh keharmonisan dan kepuasan terhadap diri dan lingkungannya.

Lingkungan sekolah adalah sebuah lingkungan yang memiliki pengaruh besar terhadap perkembangan jiwa remaja. Selain mengembangkan fungsi pengajaran, sekolah juga mengembangkan pendidikan (transformasi norma). Dalam kaitannya dengan pendidikan ini, peranan sekolah pada hakekatnya tidak jauh dari peranan keluarga, yaitu sebagai tempat rujukan dan perlindungan jika anak didik mengalami masalah.

Lingkungan merupakan sesuatu yang berada di luar manusia yang mempunyai arti bagi manusia itu sendiri. Berdasarkan pengertian tersebut, maka lingkungan sekolah merupakan sesuatu yang berada di luar diri anak (siswa) yang dapat mempengaruhi perkembangan anak (siswa) baik perkembangan fisik maupun psikisnya. Nana Sudjana (1987: 18) menyatakan bahwa lingkungan nonfisik sekolah adalah hubungan siswa dengan teman sebaya, hubungan siswa dengan guru, dan hubungan siswa dengan personil sekolah lainnya. Berdasarkan pendapat tersebut maka dapat disimpulkan bahwa penyesuaian diri di sekolah adalah kemampuan anak (siswa) untuk mempertahankan diri dalam berhubungan dan bergaul secara wajar dengan teman sebaya, guru, dan personil sekolah lainnya, sehingga dapat bertindak sesuai tuntutan lingkungan sekolah dan memperoleh kepuasan dalam hubungan tersebut.

Ciri-ciri penyesuaian diri yang baik menurut Kartini Kartono (1989: 261) adalah dapat mengendalikan pikiran, angan-angan, keinginan, dorongan emosi, dan tingkah lakunya. Dapat menghayati kelemahannya sehingga ia dapat mengadakan perbaikan diri, juga dapat memanfaatkan kelebihannya. Mempunyai konsep yang sehat tentang dirinya, yaitu mengakui dan menerima kelebihan serta kelemahannya secara rasional. Mengikuti perkembangan diri dengan berpedoman pada perbaikan, kejujuran, kebijaksanaan, rendah hati dan lain-lain. Mampu mengatasi perubahan sosial dan perubahan diri yang fleksibel. Dapat menghadapi setiap frustasi dan konflik batin dengan mekanisme yang sehat sehingga tercapai keuntungan dan kematangan diri.

Sedangkan menurut S. T. Vebriato (1990: 169), kriteria penyesuaian diri adalah kepuasan psikis, efisiensi kerja, gejala-gejala fisik, dan penerimaan sosial. Kepuasan psikis dapat terjadi setelah adanya keberhasilan penyesuaian diri. Sedangkan efisiensi kerja adalah keberhasilan menyesuaikan diri yang akhirnya dapat menampakkan kerja atau kegiatan yang efisien. Sementara gejalagejala fisik adalah tampaknya gejala-gejala seperti pusing, sakit perut, gangguan pencernaan, dan lain-lain akibat dari penyesuaian diri yang gagal. Adapun penerimaan sosial adalah timbulnya reaksi persetujuan dari masyarakat sebagai hasil dari penyesuaian.

Berdasarkan pendapat di atas, maka ciri-ciri penyesuaian diri yang baik adalah ketika seseorang dapat mengendalikan pikiran, angan-angan, keinginan, dorongan emosi, dan tingkah lakunya. Mengakui, menerima, dan memperbaiki kelemahannya secara rasional. Mampu mengatasi perubahan diri dan sosial secara fleksibel. Dapat mencapai kepuasan psikis. Dapat menampakkan efisiensi kerja. Dapat menumbuhkan penerimaan sosial serta tidak menampakkan gejala-gejala fisik yang tidak sehat akibat dari pergaulan.

\section{METODE}

Dalam penelitian ini digunakan rancangan penelitian pre-eksperimental design dengan model pre-test dan post-test 
one group design. Subjek penelitian adalah siswa kelas VII SMP Negeri 1 Diwek, Jombang yang memiliki tingkat penyesuaian diri rendah di sekolah. Siswa yang menjadi subjek penelitian sebanyak 8 orang $(\mathrm{N}=8)$ yang mendapat perlakuan bimbingan kelompok model permainan belajar bersikap. Instrumen pengumpulan data yang digunakan adalah angket kemampuan penyesuaian diri di sekolah. Kegiatan dilakukan secara berkelompok dengan menggunakan 8 teknik permainan belajar bersikap. Masing-masing teknik diterapkan dalam satu kali pertemuan.

Adapun prosedur dari eksperimen yang dilaksanakan pada penelitian ini adalah sebagai berikut.

1. Pemberian pre-test (O1) untuk mengukur tingkat kemampuan penyesuaian diri siswa di sekolah.

2. Pelaksanaan perlakuan (treatment) bimbingan kelompok model permainan belajar bersikap kepada subyek penelitian.

3. Pemberian post test (O2) untuk mengukur tingkat kemampuan penyesuaian diri siswa di sekolah setelah perlakuan.

4. Membandingkan $\mathrm{O} 1$ dan $\mathrm{O} 2$ untuk mengetahui ada tidaknya perbedaan skor kemampuan penyesuaian diri di sekolah antara sebelum dan sesudah diberi penerapan bimbingan kelompok model belajar bersikap.

Angket yang digunakan untuk mengetahui tingkat kemampuan penyesuaian diri disekolah adalah angket yang disusun oleh penulis sendiri, dimana jenis angket adalah tertutup jika dilihat dari cara menjawabnya, langsung jika dilihat dari cara menjawabnya dan check list bila dilihat dari bentuknya. Kisi-kisi angket kemampuan penyesuaian diri di sekolah, adapun indikatornya adalah dapat mengendalikan pikiran, angan-angan, keinginan, dorongan emosindan tingkah laku, mengetahui, menerima, dan memperbaiki kelemahan secara rasional, mampu mengatasi perubahan diri dan social secara fleksibel, dapat mencapai kepuasan psikis, dapat mencapai efisiensi kerja, menunjukkan penerimaan sosial dalam bergaul, dan tidak menampakkan gejala fisik yang tidak sehat. Skor jawaban angket kemampuan penyesuaian diri di sekolah dinilai dengan skor berikut.yang mereka dimiliki.

\begin{tabular}{|l|c|c|c|c|}
\hline & Selalu & Sering & $\begin{array}{l}\text { Kadang- } \\
\text { kadang }\end{array}$ & Tidak \\
\hline Favorable & 4 & 3 & 2 & 1 \\
\hline Unfavorable & 1 & 2 & 3 & 4 \\
\hline
\end{tabular}

\section{Uji validitas}

Validitas adalah suatu ukuran yang menunjukkan tingkat-tingkat kevaliditasan atau keaslian suatu instrument (Arikunto, 2006:168). Untuk mengetahui validitas instrument dalam penelitian ini yaitu angket kemampuan penyesuaian diri di sekolah adalah cara mengkorelasikan skor tiap item dengan skor total, yaitu nilai yang diperoleh pada semua item dari masing-masing indikator.

Dari hasil perhitungan validitas di atas maka dapat diketahui bahwa untuk item no.1 $t_{\text {hitung }}=0,651$ yang kemudian dikonsultasikan dengan $t_{\text {table }}$ dengan subyek $\mathrm{N}=34$ taraf signifikan $5 \%$ batas penolakan sebesar 0,339 . Dengan demikian $t_{\text {hitung }}$ lebih besar dari $t_{\text {table }}$ $(0,651>0,339)$, maka data angket penerapan bimbingan kelompok model permainan belajar.

\section{Reliabilitas}

Reliabilitas angket pada penelitian ini menggunakan teknik belah dua Spearman Brown. Hasil analisis menunjukkan bahwa angket penyesuaian diri memiliki indeks sebesar 0,962 atau dengan kata lain sangat reliabel. 


\section{HASIL DAN PEMBAHASAN}

Hasil perhitungan statistik pada instrument pengumpulan data yang dilakukan sebelum perlakuan, diketahui terdapat 8 orang siswa SMPN 1 Diwek Jombang yang teridentifikasi memiliki kemampuan penyesuaian diri di sekolah rendah yaitu : FZ memiliki skor 131 dengan kategori rendah, MA memiliki skor 121 dengan kategori rendah, ESN memiliki skor 128 dengan kategori rendah, ZR memiliki skor 122 dengan kategori rendah, ACA meiliki skor 117 dengan kategori rendah, EA memiliki skor 130 dengan kategori rendah, EE memiliki skor 128 dengan kategori rendah, dan SDC memiliki skor 123 dengan kategori rendah.

Penentuan skor tinggi diperoleh dari perhitungan mean standart deviasi (SD), yang kemudian diperoleh skor kategori rendah yaitu nilai rendah kurang dari 135 dan kategori sedang yaitu nilai antara 136 sampai 153 serta kategori tinggi dengan nilali 154 keatas. Siswa dengan skor kemampuan penyesuaian diri di sekolah kategori rendah kemudian diberi bantuan untuk meningkatkan kemampuan penyesuaian diri di sekolah tersebut dengan menggunakan bimbingan kelompok model permainan belajar sikap. Hasil yang diperoleh setelah melakukan perlakuan bimbingan kelompok model permainan belajar diketahui dari dari instrument pengumpul data yang diberikan kepada subjek penelitian.

Setelah data terkumpul sesuai dengan metode yang digunakan, langkah selanjutnya adalah menganalisis data. Hal ini dilakukan untuk mengetahui hasil penelitian yang dilakukan dengan cermat dan teliti sebab kekeliruan dalam pengumpulan data akan mengakibatkan kesalahan dalam penarikan kesimpulan. Untuk mengetahui benar atau tidaknya hipotesis yang digunakan, maka digunakan statistik non-parametrik dengan uji jenjang Wilcoxson untuk mengolah data yang terkumpul.

Setelah diberikan perlakuan, kedelapan subjek tersebut diberikan post test yang bertujuan untuk mengetahui berhasil tidaknya perlakuan bimbingan kelompok model permainan belajar bersikap yang diberikan. Dari hasil pre test dan post-test, diketahui bahwa masing-masing subjek mengalami peningkatan skor kemampuan penyesuaian diri di sekolah yang cukup beragam. Berikut dapat dilihat dari table Analisis pre-test dan post-test dengan uji Wilcoxson.

Tabel 1. Hasil analisis pre-test dan post-test kemampuan penyesuaian diri di sekolah (Uji Wilcoxon)

\begin{tabular}{|c|c|c|c|c|c|c|c|}
\hline \multirow{2}{*}{ No. } & \multirow{2}{*}{$\begin{array}{c}\text { Nama } \\
\text { Responden }\end{array}$} & $\begin{array}{c}\text { Pre- } \\
\text { test }\end{array}$ & $\begin{array}{c}\text { Post- } \\
\text { test }\end{array}$ & Beda & $\begin{array}{c}\text { Pering- } \\
\text { kat }\end{array}$ & \multicolumn{2}{|c|}{$\begin{array}{c}\text { Tanda } \\
\text { Peringkat }\end{array}$} \\
\cline { 3 - 9 } & $\mathbf{X i}$ & $\mathbf{Y i}$ & $\mathbf{( Y i - X i )}$ & $\mathbf{( Y i - X i )}$ & $(+)$ & $(-)$ \\
\hline 1 & FZ & 131 & 161 & +30 & 7 & 7 & \\
\hline 2 & MA & 121 & 148 & +27 & 4 & 4 & \\
\hline 3 & ESN & 128 & 144 & +16 & 2 & 2 & \\
\hline 4 & ZR & 122 & 150 & +28 & 5 & 5 & \\
\hline 5 & ACA & 117 & 146 & +29 & 6 & 6 & \\
\hline 6 & EA & 130 & 163 & +33 & 8 & 8 & \\
\hline 7 & EE & 128 & 143 & +15 & 1 & 1 & \\
\hline 8 & SDC & 123 & 147 & +24 & 3 & 3 & \\
\hline
\end{tabular}

Hasil dari analisis di atas menunjukkan adanya suatu perbedaan skor sebelum dan sesudah perlakuan. Hal ini berarti bimbingan kelompok model permainan belajar bersikap memiliki pengaruh positif terhadap siswa yang sebelumnya kurang mampu menyesuaikan diri di sekolah. Berdasarkan hasil analisis data dengan menggunakan $\mathrm{Uji}$ Jenjang Bertanda Wilcoxon (Wilcoxon's Signed Rank Test) terdapat perbedaan skor kemampuan penyesuaian diri di sekolah yang 
cukup signifikan. Berdasarkan tabel nilai kritis $T$ untuk Uji Jenjang Bertanda Wilcoxon dengan taraf signifikan $5 \%$ dan $N=8$ diperoleh $T_{\text {tabel }}=4$ sehingga $T_{\text {hitung }}$ lebih kecil $T_{\text {tabel }}(0<4)$ berarti $H o$ ditolak dan $H a$ diterima. Dari hasil tersebut dapat ditarik kesimpulan bahwa bimbingan kelompok model permainan belajar bersikap mampu meningkatkan kemampuan penyesuaian diri siswa di sekolah. Dengan demikian hipotesis peneliti yang berbunyi "Terdapat perbedaan yang signifikan dalam skor penyesuaian diri sebelum dan sesudah penerapan bimbingan kelompok model permainan belajar bersikap pada siswa kelas VII SMP Negeri 1 Diwek, Jombang" dapat diterima.

Artinya, bahwa dengan penerapan bimbingan kelompok model permainan belajar bersikap peserta kelompok diajak melakukan latihan atau permainan belajar bersikap yang bertujuan untuk mendorong peserta agar mampu belajar dari pengalaman yang telah diperolehnya dalam kegiatan kelompok. Hal ini sesuai dengan pendapat Prasetyo (2007: 68) yang mengungkapkan bahwa melalui kegiatan bermain individu akan memperoleh berbagai pengalaman yang dapat digunakan untuk memperbaiki hubungan antarmanusia dan mengenal diri sendiri dengan lebih baik.

Aktifitas kelompok diarahkan untuk memperbaiki dan mengembangkan pemahaman diri dan lingkungan, penyesuaian diri serta pengembangan diri (Juntika, 2006 : 23). Dengan permainan peserta didik dapat melampiaskan dorongan-dorongan emosinya sehingga tercipta perasaan lega dan puas.suasana menyenangkan dan santai yang tercipta selama permainan berlangsung akan menimbulkan suatu pengalaman tersendiri bagi peserta didik yang kemudian akan direnungkan untuk menyadari perasaan dan reaksi mereka. Dinamika kelompok yang terbentuk selama permainan berlangsung akan mendorong peserta layanan untuk mampu melakukan interaksi social sehingga peserta didik akan mampu menyesuaikan diri.
Dalam pelaksanaan sebanyak 8 kali pertemuan, peneliti tidak lepas dari berbagai hambatan. Adapun hambatan yang dirasakan adalah terbatasnya ruangan yang tersedia dikarenakan ruangan konseling sedang direnovasi. Disamping itu, peserta kelompok dapat bermain secara sportif karena menginginkan kelompoknya menjadi pemenang. Untuk mengatasi hambatan tersebut, peneliti memanfaatkan ruang perpustakaan untuk pelaksanaan permainan. Selain itu, pemberian rasional permainan harus dilakukan dengan jelas agar peserta memahami aturan-aturan permainan serta tujuan yang ingin dicapai.

\section{SIMPULAN DAN SARAN}

Berdasarkan hasil analisis dapat disimpulkan bahwa terdapat perbedaan yang signifikan pada skor penyesuaian diri di sekolah sebelum dan sesudah penerapan bimbingan kelompok model permainan belajar bersikap pada siswa kelas VII SMP Negeri yang menjadi subjek penelitian ini. Berdasarkan simpulan tersebut di atas, maka hasil penelitian ini memberikan beberapa rekomendasi sebagai berikut: Pertama, bagi konselor sekolah diharapkan mampu memperkaya model-model permainan yang dapat digunakan untuk membantu penyelesaian permasalahan siswa di sekolah; Kedua, kepada peneliti lain yang ingin mengadakan penelitian dalam bentuk bimbingan kelompok disarankan untuk menerapkan model lain sehingga bisa menambah kekayaan teknik bimbingan kelompok dalam menangani permasalahan peserta didik khususnya permasalahan penyesuaian diri di sekolah. 


\section{DAFTAR PUSTAKA}

Hurlock, B. Elizabeth. 1993. Psikologi Perkembangan. Jakarta: Erlangga.

Kartono, Kartini. 1989. Hygiene Mental dan Kesehatan Mental Dalam Islam. Bandung: Mandar Maju.

Martini. 2005. Prosedur dan Prinsip-prinsip Statistika. Surabaya: UNESA University Press.

Mulyono, Tri dan Setya Haji Winarna. 2002. Bermain Belajar Bersikap. Surabaya: Plan Indonesia.

Nurihsan, Achmad Juntika. 2006. Bimbingan dan Konseling Dalam Berbagai Latar Kehidupan. Bandung: Refika Aditama.

Nursalim, Mochamad dan Suradi. 2002. Layanan Bimbingan dan Konseling. Surabaya: UNESA University Press.

Panuju, Panut dan Ida Umami. 2005. Psikologi Remaja. Yogyakarta: Tiara Wacana.

Prasetyo, Dwi Sunar. 2007. Membedah Psikologi Bermain Anak. Yogyakarta: Think.
Rumini, Sri dan Sundari Siti. 2004. Prekembangan Anak dan Remaja. Jakarta: Rineka Cipta.

Sudjana, Nana. 1987. Dasar-dasar Proses Belajar Mengajar. Bandung: Sinar Baru.

Sunarto dan Hartono Agung. 1999. Perkembangan Peserta Didik. Jakarta: Rieneka Cipta.

Tohirin. 2007. Bimbingan dan Konseling di Sekolah dan Madrasah (Berbasis Integrasi). Jakarta: Raja Grafindo Persada.

Vebriarto, S. T. 1999. Sosiologi Pendidikan. Yogyakarta: Andi Offset.

Willis, Sofyan. 1994. Problem Remaja dan Pemecahannya. Bandung: Angkasa. 2005. Remaja dan Masalahnya. Bandung: Alfabeta. 